\title{
OPTIMIZATION OF ALKALINE HYDROLYSIS OF CHROME SHAVINGS TO RECOVER COLLAGEN HYDROLYSATE AND CHROMIUM HYDROXIDE
}

\author{
Julio BARRA HINOJOSA*, Liliana MARRUFO SALDAÑA \\ Productive Innovation and Technological Transfer Center of Leather, Footwear and related industries (CITEccal Lima), \\ Technological Institute of Production (ITP), Caquetá Ave. 1300, Rímac, 15094, Lima, Perú, Imarrufo@itp.gob.pe, \\ julio.barra.h@uni.pe
}

Received: 02.10.2019

Accepted: 22.01.2020

https://doi.org/10.24264/Ifj.20.1.2

OPTIMIZATION OF ALKALINE HYDROLYSIS OF CHROME SHAVINGS TO RECOVER COLLAGEN HYDROLYSATE AND CHROMIUM HYDROXIDE

ABSTRACT. The tanning industry uses skins and hides from cattle, sheep, among others, which are a byproduct of the meat industry. In their production process, they generate wastewater and solid wastes in significant quantities, that require alternatives for their adequate treatment. The present research was developed to optimize the alkaline hydrolysis process of chrome leather shavings to recover collagen hydrolysate and chromium salts, and to identify the relation between the response variables and hydrolysis conditions. For this purpose, a preliminary study was carried out, where alkaline hydrolysis conditions were adjusted, then these were optimized through a factorial design and scaled up the process to a pilot level. The preliminary study of alkaline hydrolysis of the sample was performed, where reaction time and sodium hydroxide concentration were established as factors to adjust the process. The optimization of this method was developed through a factorial design with two response variables: percentage of recovered collagen protein (PRCP) and percentage of residual chromium (PRC) present in the collagen hydrolysate. Thus, the optimum alkaline hydrolysis conditions were obtained: $70^{\circ} \mathrm{C}, 0.47 \mathrm{M} \mathrm{NaOH}$ and 90 minutes for the reaction, and the relation between the response variables. Finally, the process was carried out in a pilot scale in which $45 \mathrm{~L}$ of collagen hydrolysate was recovered, with $87.16 \%$ of recovered collagen protein and $1.17 \%$ of residual chromium.

KEY WORDS: waste valorization, chrome shavings, alkaline hydrolysis, tanning process

OPTIMIZAREA PROCESULUI DE HIDROLIZĂ ALCALINĂ A RĂZĂTURII DE PIELE CROMATĂ PENTRU A VALORIFICA HIDROLIZATUL DE COLAGEN ŞI HIDROXIDUL DE CROM

REZUMAT. Industria de pielărie foloseşte piei de bovine și ovine, printre altele, care sunt un produs secundar al industriei cărnii. În procesul de producţie, acestea generează ape uzate şi deşeuri solide în cantităţi semnificative, care necesită alternative pentru tratarea lor adecvată. Acest studiu de cercetare a fost dezvoltat cu scopul de a optimiza procesul de hidroliză alcalină a răzăturii de piele cromată pentru a valorifica hidrolizatul de colagen şi sărurile de crom şi pentru a identifica relaţia dintre variabilele de răspuns şi condiţiile de hidroliză. În acest scop, s-a efectuat un studiu preliminar, în care au fost ajustate condiţiile de hidroliză alcalină, apoi acestea au fost optimizate printr-un plan factorial experimental şi s-a extins procesul la nivel pilot. S-a efectuat studiul preliminar al hidrolizei alcaline a probei, în care timpul de reacţie şi concentraţia de hidroxid de sodiu au reprezentat factori de ajustare a procesului. Această metodă s-a optimizat printr-un plan factorial experimental cu două variabile de răspuns: procentul de proteine recuperate din colagen (PRCP) şi procentul de crom rezidual (PRC) prezent în hidrolizatul de colagen. Astfel, au fost obţinute condiţiile optime pentru hidroliza alcalină: $70^{\circ} \mathrm{C}, \mathrm{NaOH} 0,47 \mathrm{M}$ şi 90 minute pentru reacţie, precum şi relaţia dintre variabilele de răspuns. În cele din urmă, procesul s-a desfăşurat la nivel pilot, recuperându-se $45 \mathrm{~L}$ de hidrolizat de colagen, cu $87,16 \%$ proteine recuperate din colagen şi $1,17 \%$ crom rezidual.

CUVINTE CHEIE: valorificarea deşeurilor, răzătură de piele cromată, hidroliză alcalină, proces de tăbăcire

\section{OPTIMISATION DE L'HYDROLYSE ALCALINE DE COPEAUX DE CHROME POUR RECUPERER L'HYDROLYSAT DE COLLAGENE ET L'HYDROXYDE} DE CHROME

RÉSUMÉ. L'industrie de la tannerie utilise des peaux de bovins et de moutons, entre autres, qui sont un sous-produit de l'industrie de la viande. Dans leur processus de production, ils génèrent des eaux usées et des déchets solides en quantités importantes, qui nécessitent des solutions alternatives pour leur traitement adéquat. La présente recherche a été développée pour optimiser le processus d'hydrolyse alcaline des copeaux de cuir chromé afin de récupérer l'hydrolysat de collagène et les sels de chrome, et pour identifier la relation entre les variables de réponse et les conditions d'hydrolyse. À cette fin, une étude préliminaire a été réalisée ; les conditions d'hydrolyse alcaline ont été ajustées, puis optimisées grâce à une conception factorielle et à une mise à l'échelle du processus à un niveau pilote. L'étude préliminaire de l'hydrolyse alcaline de l'échantillon a été réalisée. Le temps de réaction et la concentration en hydroxyde de sodium ont été établis comme facteurs permettant d'ajuster le processus. L'optimisation de cette méthode a été développée selon un plan factoriel avec deux variables de réponse : le pourcentage de protéine de collagène récupérée (PRCP) et le pourcentage de chrome résiduel (PRC) présent dans l'hydrolysat de collagène. Ainsi, les conditions optimales d'hydrolyse alcaline ont été obtenues : $70^{\circ} \mathrm{C}, \mathrm{NaOH} 0,47 \mathrm{M}$ et 90 minutes pour la réaction et la relation entre les variables de réponse. Enfin, le processus a été mis en œuvre à une échelle pilote dans laquelle on a récupéré $45 \mathrm{~L}$ d'hydrolysat de collagène, avec $87,16 \%$ de protéine de collagène récupérée et $1,17 \%$ de chrome résiduel. MOTS CLÉS: valorisation des déchets, copeaux de chrome, hydrolyse alcaline, procédé de tannage

\footnotetext{
* Correspondence to: Liliana MARRUFO SALDAÑA and Julio BARRA HINOJOSA, Productive Innovation and Technological Transfer Center of Leather, Footwear and related industries (CITEccal Lima), Technological Institute of Production (ITP), Caquetá Ave. 1300, Rímac, 15094, Lima, Perú,Imarrufo@itp.gob.pe, julio.barra.h@uni.pe
} 


\section{INTRODUCTION}

In recent years, there has been a significant increase in the generation of solid waste globally. For diverse industries, this has provoked a special interest, since most of the times and depending on their characteristics, these residues are not being treated adequately, originating problems that affect the health of the human being and the environment. Facing this situation, an innovative alternative proposed for waste management is the valorization, which allows them to be recovered and reused depending on their composition and characteristics [1].

The tanning industry converts skins and hides into a flexible, non-putrescible and durable leather, necessary for the production of various goods, such as shoes, wallets, clothing, among others. The tanning process generates different waste in large volumes, which is why companies in this sector require alternatives to manage them properly. The wastes that cause more concerns are tanned wastes, especially those that contain chromium in their composition [2]. The largest amount of chrome-tanned wastes is produced in the shaving stage, where the leathers are shaved to give them a uniform thickness, and the waste generated is known as leather shavings or chrome shavings. This residue represents about $10 \%$ by weight of the hides that enter the tanning process, for each ton of leather processed, producing about 100 $\mathrm{kg}$ of shavings $[1,3,4]$.

Chrome shavings contain chromium $(\mathrm{Cr})$ in the +3 oxidation state $\left(\mathrm{Cr}_{2} \mathrm{O}_{3}\right)$, and the content can vary between 2.5 and $6 \%[5,6]$, besides that, they have a high calorific value and must be disposed of as a hazardous waste [7]. Traditionally, chrome shavings are disposed of in landfills and mostly, deposited in dumps or around tanneries [1]. Hence, these residues are exposed to conditions that allow $\mathrm{Cr}$ as +3 and +6 oxidation states, producing very toxic chemical species with carcinogenic properties [8, 9]. Therefore, its inadequate final disposition shows a risk factor for the health of human beings and environment [10].

Despite the characteristics mentioned above, these residues have a great potential to be valorized, because of their high amount of collagen, which is a natural protein present in the skin and represents most of its composition and provides the leather the characteristics of resistance and durability $[1,5,11]$. In reports before1970, differentresearchershavedeveloped alternatives to apply leather shavings, such as insulators, building material, fibrous sheets and shoe soles [12]. Since 1970, a lot of researchers have approached the collagen recovery from chrome shavings through hydrolysis methods. Literature shows projects that aimed to analyze the characteristics of chrome shavings hydrolysis and the applications of the products, Jiang et al. [13] applied alkaline hydrolysis with $\mathrm{CaO}$, to extract protein and chrome, the recovered protein was mixed with substrates and used as feed collagen powder, also the behavior of alkaline hydrolysis conditions $(\mathrm{pH}$, temperature and reaction time) were studied. Tahiri et al. [11] treated chrome shavings with sodium hydroxide where optimized hydrolysis conditions at $\mathrm{NaOH}$ $0,5 \mathrm{M}, 15$ minutes of reaction time at boiling point, to recover proteins and chrome cake, transform it into basic chromium sulfates and tested it in tanning operations. Beltrán-Prieto and Kolomaznik [14] applied an experimental design to optimize the conditions of chromium oxide recovery in the chromium cake through alkaline hydrolysis with sodium hydroxide, the optimum values identified were $1,58 \% \mathrm{NaOH}$ concentration, $63,7^{\circ} \mathrm{C}, 3$ hours reaction time and solid/liquid ratio $1 / 70 \mathrm{~g} / \mathrm{mL}$. Scopel et al. [15] recovered collagen through alkaline hydrolysis; reaction time, temperature, stirring rate and alkali ( $\mathrm{CaO}$ and $\mathrm{MgO}$ ) were controlled, to obtain a hydrolysate with high protein content $(2,2 \mathrm{~g} / \mathrm{L}$ NTK) and low chromium content $(<0,04 \mathrm{mg} / \mathrm{L})$. Pahlawan et al. [16] treated chrome shavings to recover hydrolysate useful for protein binder production, the hydrolysis condition evaluated were sodium hydroxide concentration $(1,2$ and $3 \%)$, reaction time $(1,2$ and 3 hours) reacting at $90^{\circ} \mathrm{C}$, after reaction the hydrolysates were characterized on protein content $(6,64 \%)$, chromium content $(47,55 \mathrm{ppm})$, viscosity $(16,9$ $\mathrm{cp}$ ) and types of amino acids. The present study aimed to develop the optimization of alkaline hydrolysis with $\mathrm{NaOH}$, through the simultaneous optimization of both response variables percentage of recovered collagen protein (PRCP) and percentage of residual chromium (PRC) and analyze them. Moreover, the optimized condition was carried out at pilot scale, in a reactor to evaluate the possibility of scaled production. 


\section{EXPERIMENTAL}

\section{Materials and Methods}

\section{Raw Material}

Chrome shavings were obtained from a tannery in the district of "San Juan de Lurigancho", Lima. The waste was stored under controlled conditions of moisture (65\% RH) and temperature $\left(20^{\circ} \mathrm{C}\right)$ for conservation. The shavings were characterized, in a laboratory accredited by ISO 17025 , for the parameters of Total Kjeldahl Nitrogen (TKN) by NTP 201.021: 2002 (Revisada 2015) CARNE Y PRODUCTOS CÁRNICOS. Determinación del contenido de proteínas, moisture by NTP ISO 1442: 2006 (Rev 2015) CARNE Y PRODUCTOS CÁRNICOS. Determinación del contenido de humedad, total protein by NTP 201.021: 2002 (Revisada 2015) CARNE Y PRODUCTOS CÁRNICOS. Determinación del contenido de proteínas, ash by AOAC 920.153 , On line $20^{\text {th }} \mathrm{Ed}$. 2016 Ash of Meat, fat by NTP 201.016: 2002 CARNE Y PRODUCTOS CÁRNICOS. Determinación del contenido de grasa total, and pH by NTP ISO 4045: 2008 [1, 11].

\section{Hydrolysis Processes}

The hydrolysis treatments of chrome shavings were carried out on a laboratory scale. To ensure the homogeneity of the shavings, they were pretreated through grinding by defibrillator method. The hydrolysis system was prepared, comprising a flat-bottomed ball flask, soxhlet equipment, and a magnetic stirring plate. A quantity of pretreated shavings and sodium hydroxide $(\mathrm{NaOH})$ solution was added into the flask, the sample was mixed and according to the concentration of $\mathrm{NaOH}$ the $\mathrm{pH}$ varied between 10-12.5, then it was heated on a stove to the desired temperature of $70^{\circ} \mathrm{C}$, optimum temperature in previous research [15, 17-19], after which the flask was installed in the hydrolysis system, and the reaction time began to be controlled.

After the reaction, the solution was centrifuged to separate the resulting products, collagen hydrolysate and chromium cake, which were stored in glass bottles and Ziplock bags for further analysis. Figure 1 presents the diagram of alkaline hydrolysis processes at laboratory scale.

\section{Preliminary Study}

To adjust the variables of the alkaline hydrolysis process, a preliminary study was carried out, in which the levels of $\mathrm{NaOH}$ concentration and reaction time were tested. The results were obtained through the measurement of soluble solids expressed in Brix degrees ( $\left.{ }^{\circ} \mathrm{Bx}\right)$ using a refractometer [20], acting as an indirect indicator of the presence of dissolved collagen in the hydrolysate as the collagen is the main dissolved component in the hydrolysate, so it allowed the comparison of recovered collagen between treatments faster than other methods. This method was applied as a recommendation from researchers of Technological Institute of Production laboratory.

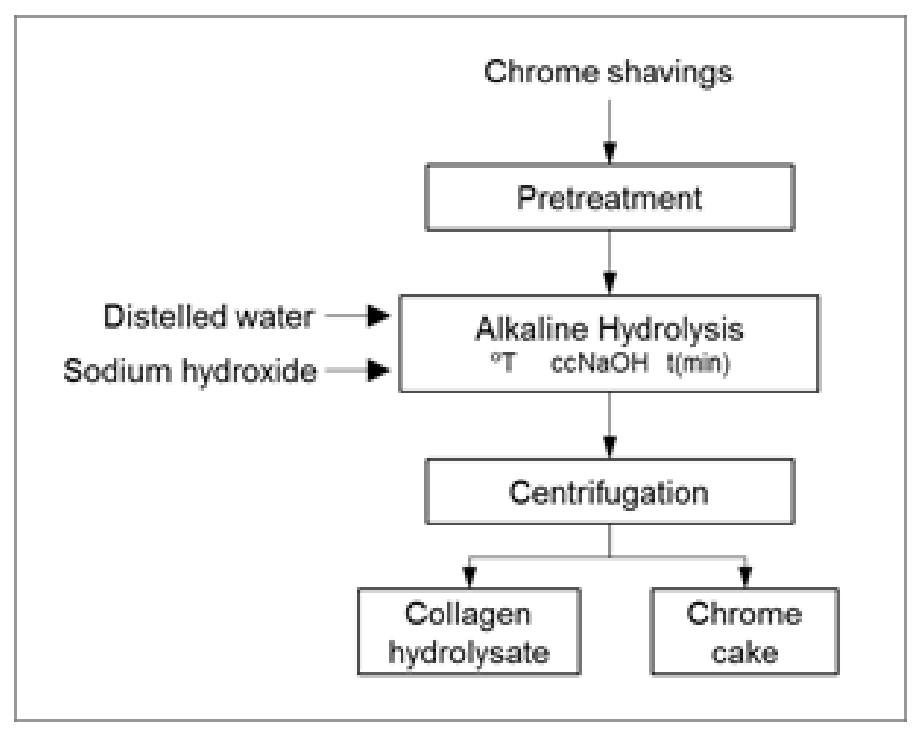

Figure 1. Alkaline hydrolysis process 
Experimental Design

To optimize the alkaline hydrolysis process, a $3^{2}$ factorial design was developed in which the factors, concentration of $\mathrm{NaOH}$ and reaction time were tested with respect to the response variables: the percentage of recovered collagen protein (PRCP) and percentage of residual chromium (PRC) present in the collagen hydrolysate. The $3^{2}$ factorial design comprised 9 treatments, that were carried out in duplicate. The graphics and analysis were carried out on Statgraphics Centurion XVI.

The PRCP was characterized by determining the total nitrogen content by Kjeldahl method and the PRC by EPA method 200.8, Rev 5.4: 1994. Determination of Trace Elements in Waters and Wastes by Inductively Coupled Plasma - Mass Spectroscopy). These results were compared with those obtained in the characterization of the chrome shavings.

Likewise, the levels for the $3^{2}$ factorial design were established using the results of the preliminary study. The model of $3^{2}$ factorial design is presented below.

$Y_{i j k}=\mu+\gamma_{i}+\delta_{j}+(\gamma \delta)_{i j}+\varepsilon_{i j k}$

with $i=1,2,3 ; j=1,2,3 ; k=1,2$

Where:

$Y_{i j k}=$ Effect of the treatment

$\mu=$ Overall mean effect

$V_{i}=$ Effect of the ${ }_{i}$ th level of factor $\mathrm{A}$

$\delta_{j}=$ Effect of the ${ }_{j}$ th level of factor B

$(\gamma \delta)_{i j}=$ Interaction effect between factors $A$ and $B$ in levels $i j$

$k=$ Number of replicates

$\varepsilon_{i j k}=$ Random error

The hypothesis tests for $3^{2}$ factorial design are used to check whether the effect of the factors investigated is significant or not, as follows:

$H_{0}: \nu_{1}=\nu_{2}=\gamma_{3}=0$ (Main effect of $A$ is absent)

$H_{0}: v_{i} \neq 0$ for at least one $i$

$H_{0}: \delta_{1}=\delta_{2}=\delta_{3}=0$ (Main effect of $B$ is absent)

$H_{0}: \delta_{i} \neq 0$ for at least one $j$

$H_{0}:(\nu \delta)_{11}=(\gamma \delta)_{12}=\ldots=(\nu \delta)_{33}=0$ (Interaction $A B$ is absent)
$H_{0}:(\gamma \delta)_{i j} \neq 0$ for at least one ij

These hypothesis are tested in the analysis of variance (ANOVA) through $\mathrm{F}$ test. For factorial design, the $\mathrm{F}$ test is used to obtain $\mathrm{p}$-value, which is used to test the hypothesis for each factor, at $95 \%$ confidence, whether $p$-value is lower than 0.05 , the effect of the factor is significant (while lowest the $p$-value is, the factor presents a more significant effect), or $p$-value higher than 0.05 , the effect of the factor is absent.

\section{Scaling to Pilot Level}

Once the variables of alkaline hydrolysis at laboratory scale were optimized, the process was carried out on a pilot scale, in a reactor of 60 L. The hydrolysate obtained was characterized by determining the total nitrogen content (Kjeldahl method) and total chromium content by EPA 200.8, Rev 5.4: 1994. Determination of Trace Elements in Waters and Wastes by Inductively Coupled Plasma - Mass Spectroscopy).

\section{RESULTS AND DISCUSSIONS}

\section{Characterization of Chrome Shavings}

The characterization of the shavings allowed to establish the maximum content of recoverable protein and chromium through hydrolysis, the remaining parameters allow identifying the impurities present, which will be part of the chromium cake at the end of the hydrolysis process. Thus, the shavings contain $11.44 \%$ of total nitrogen, $21.13 \%$ of moisture, $63.52 \%$ of collagen protein, $16323.79 \mathrm{mg} / \mathrm{kg}$ of total chromium, $3.02 \%$ of chromium oxide, $8.34 \%$ of ashes, and $0.14 \%$ of fats with $\mathrm{pH}$ of 3.75. The results match the published reports $[1,11]$.

\section{Preliminary Study}

The working conditions for the treatments evaluated in the preliminary study are presented in Table 1. 
Table 1: Alkaline hydrolysis treatments

\begin{tabular}{ccc}
\hline $\begin{array}{c}\text { Chrome shavings (g) } \\
\text { Water Quantity (mL) }\end{array}$ & \multicolumn{2}{c}{10} \\
\hline \multirow{2}{*}{ Sample code } & Time & cc NaOH \\
& $(\mathrm{min})$ & $(\mathrm{M})$ \\
\hline & 30 & 0.1 \\
VC-HC-A & 45 & 0.1 \\
& 60 & 0.1 \\
& 90 & 0.1 \\
& 120 & 0.1 \\
VC-HC-B & 30 & 0.3 \\
& 45 & 0.3 \\
& 60 & 0.3 \\
& 90 & 0.3 \\
& 120 & 0.3 \\
VC-HC-C & 30 & 0.5 \\
& 45 & 0.5 \\
& 60 & 0.5 \\
& 90 & 0.5 \\
& 120 & 0.5 \\
\hline
\end{tabular}

The results in ${ }^{\circ} \mathrm{Bx}$ for each treatment in the preliminary study are shown in Table 2.

Table 2: Results of the preliminary study

\begin{tabular}{|c|c|c|c|c|c|c|c|}
\hline \multirow[b]{2}{*}{ Processing code } & \multirow{2}{*}{$\begin{array}{c}\mathrm{cc} \mathrm{NaOH} \\
\text { (M) }\end{array}$} & \multirow{2}{*}{${ }^{\circ} \mathrm{Bx} \mathrm{NaOH}$} & \multicolumn{5}{|c|}{ oBx Time (minutes) } \\
\hline & & & $30^{\prime}$ & $45^{\prime}$ & $60^{\prime}$ & $90^{\prime}$ & $120^{\prime}$ \\
\hline VC-HC-A & 0.1 & 1.0 & 0.6 & 0.6 & 0.4 & 0.4 & 0.4 \\
\hline VC-HC-B & 0.3 & 2.2 & 7.8 & 7.8 & 7.4 & 7.2 & 7.0 \\
\hline VC-HC-C & 0.5 & 4.0 & 6.8 & 6.6 & 6.6 & 6.6 & 6.6 \\
\hline
\end{tabular}

In the VC-HC-A treatments, carried out with $\mathrm{NaOH} 0.1 \mathrm{M}$, low values of soluble solids between 0.4 and $0.6^{\circ} \mathrm{Bx}$ were obtained after centrifugation of the samples. All treatments presented a colorless supernatant and a

chromium cake with a consistency similar to the hydrated shavings (Figure 2), establishing that the reaction time did not influence the concentration of collagen and residual chromium in the solution.

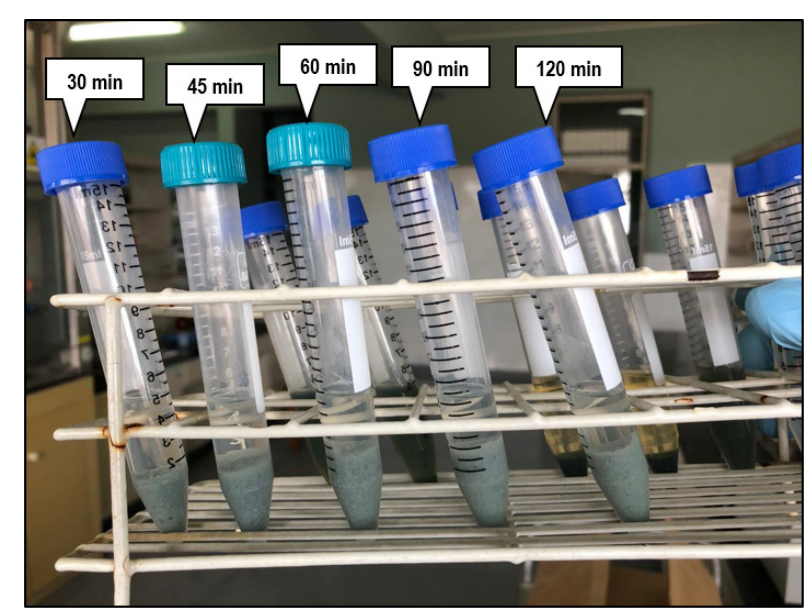

Figure 2. VC-HC-A Treatment

In the VC-HC-B treatments, with $\mathrm{NaOH} 0.3$ $M$, higher values of $B$ rix degrees were reached, in a range of 7.8 to $7.0^{\circ} \mathrm{Bx}$. These levels are due to the effect of hydrolysis of the chrome shavings, resulting in the presence of dissolved chromium in the hydrolysate. However, the values ( $\left.{ }^{\circ} \mathrm{Bx}\right)$ decreased as the reaction time increased. At the longer reaction time, under the established temperature conditions, the chromium concentration decreased while precipitating 
into the cake, which was presented as a residue sludge. These conclusions can also be seen in the coloration of the solutions (Figure 3 ).

Figure 3 shows that after 30 minutes of reaction, the hydrolyzed solution turned into green color, similar to a dissolution of a $\mathrm{Cr}$ (III) salt, which indicates the presence of this metal. As the reaction moves, the solution becomes yellowish, a sign of the decrease in chromium concentration in the solution.

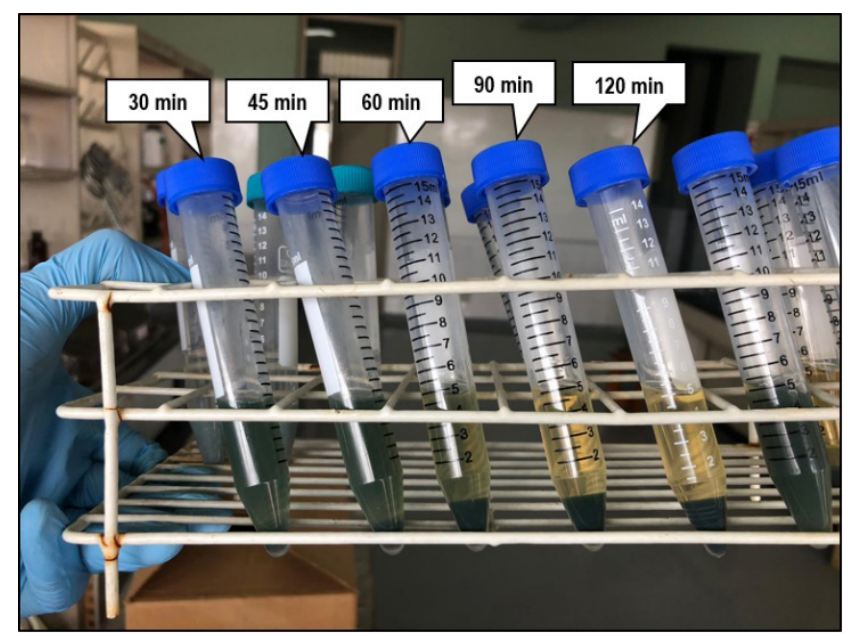

Figure 3. VC-HC-B Treatment

Finally, in the VC-HC-C treatments performed with $\mathrm{NaOH} 0.5 \mathrm{M}$, the Brix value at a time of 30 minutes was $6.8^{\circ} \mathrm{Brix}$, and $6.6^{\circ}$ for the remaining times. It was also observed that for the individual centrifuged treatments, the color of the solution was kept in a yellowish tone, and the cake presented a muddy consistency.

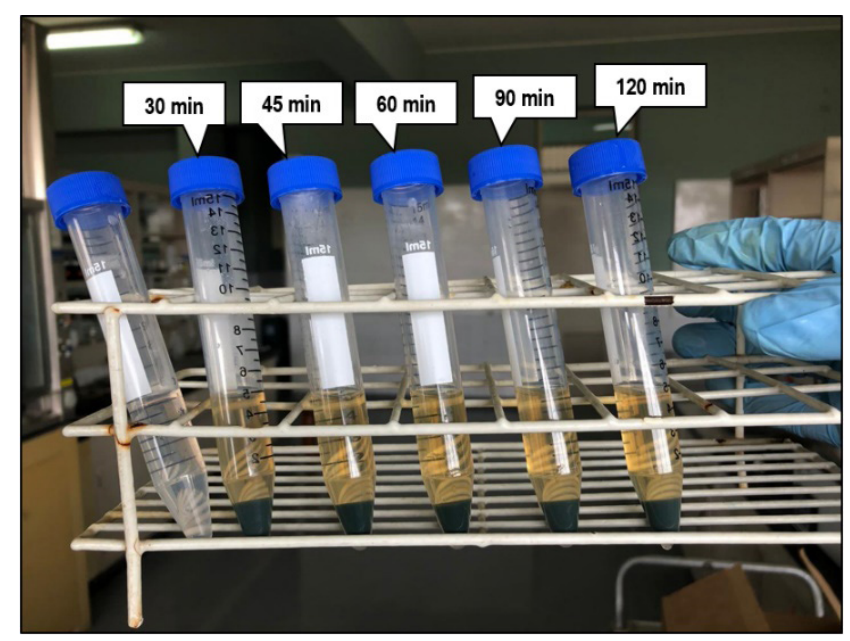

Figure 4. VC-HC-C Treatment

\section{Evaluation of the Experimental Design}

Using the results of preliminary study, the levels of variables were established for a $3^{2}$ factorial design, where each treatment was carried out in duplicate. The levels and treatments of $3^{2}$ factorial design are presented in figure 5. 


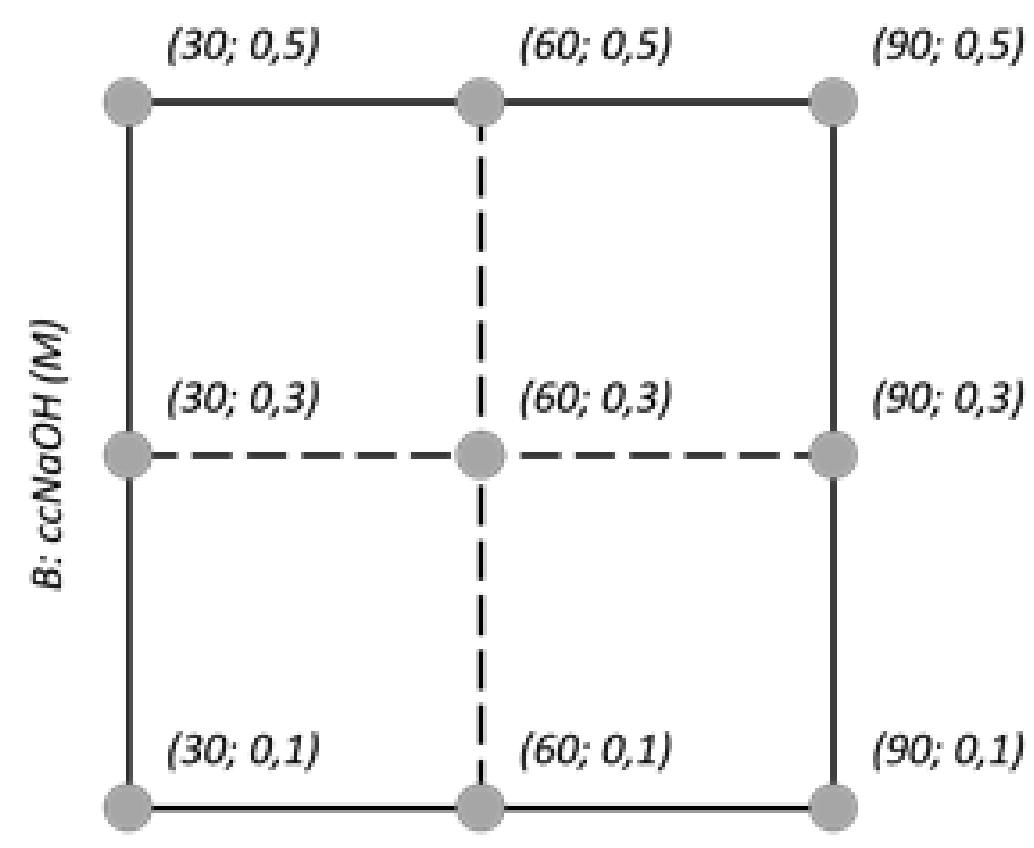

\section{A: Time ( $\min )$}

Figure $5.3^{2}$ factorial design

Table 3 shows the results of PRCP and PRC in the collagen hydrolysate obtained for each treatment.

Table 3: Results of Factorial design treatments

\begin{tabular}{|c|c|c|c|c|}
\hline \multirow{2}{*}{\multicolumn{3}{|c|}{$\begin{array}{c}\text { Chrome shavings (g) } \\
\text { Quantity of water }\end{array}$}} & \multicolumn{2}{|c|}{10} \\
\hline & & & $1000 \%$ & $100 \mathrm{~mL}$ \\
\hline \multicolumn{3}{|c|}{ Rx temperature $\left({ }^{\circ} \mathrm{C}\right)$} & \multicolumn{2}{|c|}{$70^{\circ} \mathrm{C}$} \\
\hline & $A$ & $B$ & R1 & R2 \\
\hline Sample code & $\begin{array}{l}\text { Time } \\
(\min )\end{array}$ & $\begin{array}{l}\mathrm{CC} \mathrm{NaOH} \\
\text { (M) }\end{array}$ & $\begin{array}{l}\text { PRCP } \\
(\%)\end{array}$ & $\begin{array}{l}\text { PRC } \\
(\%)\end{array}$ \\
\hline VC-HC-01 & 30 & 0,1 & 1,065 & 0,924 \\
\hline VC-HC-02 & 60 & 0,1 & 0,794 & 0,129 \\
\hline VC-HC-03 & 90 & 0,1 & 7,577 & 8,413 \\
\hline VC-HC-04 & 30 & 0,3 & 86,504 & 84,798 \\
\hline VC-HC-05 & 60 & 0,3 & 78,156 & 6,936 \\
\hline VC-HC-06 & 90 & 0,3 & 82,733 & 1,661 \\
\hline VC-HC-07 & 30 & 0,5 & 83,296 & 4,932 \\
\hline VC-HC-08 & 60 & 0,5 & 85,618 & 2,200 \\
\hline VC-HC-09 & 90 & 0,5 & 80,088 & 1,811 \\
\hline VC-HC-10 & 30 & 0,1 & 1,029 & 2,551 \\
\hline VC-HC-11 & 60 & 0,1 & 0,729 & 0,370 \\
\hline VC-HC-12 & 90 & 0,1 & 6,287 & 0,076 \\
\hline VC-HC-13 & 30 & 0,3 & 87,385 & 88,682 \\
\hline VC-HC-14 & 60 & 0,3 & 75,338 & 23,757 \\
\hline VC-HC-15 & 90 & 0,3 & 78,502 & 1,578 \\
\hline VC-HC-16 & 30 & 0,5 & 84,107 & 2,695 \\
\hline VC-HC-17 & 60 & 0,5 & 80,754 & 2,186 \\
\hline VC-HC-18 & 90 & 0,5 & 82,776 & 1,760 \\
\hline
\end{tabular}

*Treatments from VC-HC-01 to VC-HC-09 correspond to the first run, and VC-HC-10 to VC-HC-18 to the second run. 
The results obtained were used to analyze variance for each response variable, whose ANOVA results are presented in Tables 4 and 5.

Table 4: ANOVA of the PRCP

\begin{tabular}{lrrrrr}
\hline Source & Sum of Squares & $\begin{array}{c}\text { Degree of } \\
\text { freedom }\end{array}$ & Mean squares & F-Ratio & P-value \\
\hline A: Time & 2.452 & 1 & 2.452 & 0.738 & 0.4127 \\
B: $c$ cNaOH & 19132.738 & 1 & 19132.738 & 5755.932 & 0.0000 \\
$A^{2}$ & 41.329 & 1 & 41.329 & 12.433 & 0.0065 \\
$B^{2}$ & 5957.681 & 1 & 5957.681 & 1792.321 & 0.0000 \\
$A B$ & 33.251 & 1 & 33.251 & 10.003 & 0.0115 \\
$A^{2} B$ & 9.865 & 1 & 9.865 & 2.968 & 0.1190 \\
$A^{2}$ & 44.123 & 1 & 44.123 & 13.274 & 0.0054 \\
$A^{2} B^{2}$ & 29.181 & 1 & 29.181 & 8.779 & 0.0159 \\
Error & 29.916 & 9 & 3.324 & & \\
Total & 25280.536 & 17 & & & \\
\hline
\end{tabular}

In the ANOVA results of the PRCP, the concentration were identified as significant in linear and quadratic effects of sodium hydroxide protein recovery.

Table 5: ANOVA of the PRC

\begin{tabular}{lrrrrr}
\hline Source & Sum of Squares & $\begin{array}{c}\text { Degree of } \\
\text { freedom }\end{array}$ & Mean square & F-Ratio & P-value \\
\hline A: Time & 2388.066 & 1 & 2388.066 & 114.556 & 0.0000 \\
$\mathrm{~B}: \mathrm{ccNaOH}$ & 0.812 & 1 & 0.812 & 0.039 & 0.8479 \\
$\mathrm{~A}^{2}$ & 460.291 & 1 & 460.291 & 22.080 & 0.0011 \\
$\mathrm{~B}^{2}$ & 4155.442 & 1 & 4155.442 & 199.338 & 0.0000 \\
$\mathrm{AB}$ & 10.283 & 1 & 10.283 & 0.493 & 0.5002 \\
$\mathrm{~A}^{2} \mathrm{~B}$ & 3.040 & 1 & 3.040 & 0.146 & 0.7114 \\
$\mathrm{AB}^{2}$ & 4857.499 & 1 & 4857.499 & 233.016 & 0.0000 \\
$\mathrm{~A}^{2} \mathrm{~B}^{2}$ & 655.645 & 1 & 655.645 & 31.452 & 0.0003 \\
Error & 187.616 & 9 & 20.846 & & \\
Total & 12718.694 & 17 & & & \\
\hline
\end{tabular}

From the ANOVA of the PRC, the linear effect of reaction time, the quadratic effect of sodium hydroxide concentration and the interaction effect of both variables were determined as significant in the content of chrome in the hydrolysate.

The behavior of the process variables was also analyzed through the main effects plots shown in Figures 6 and 7. 


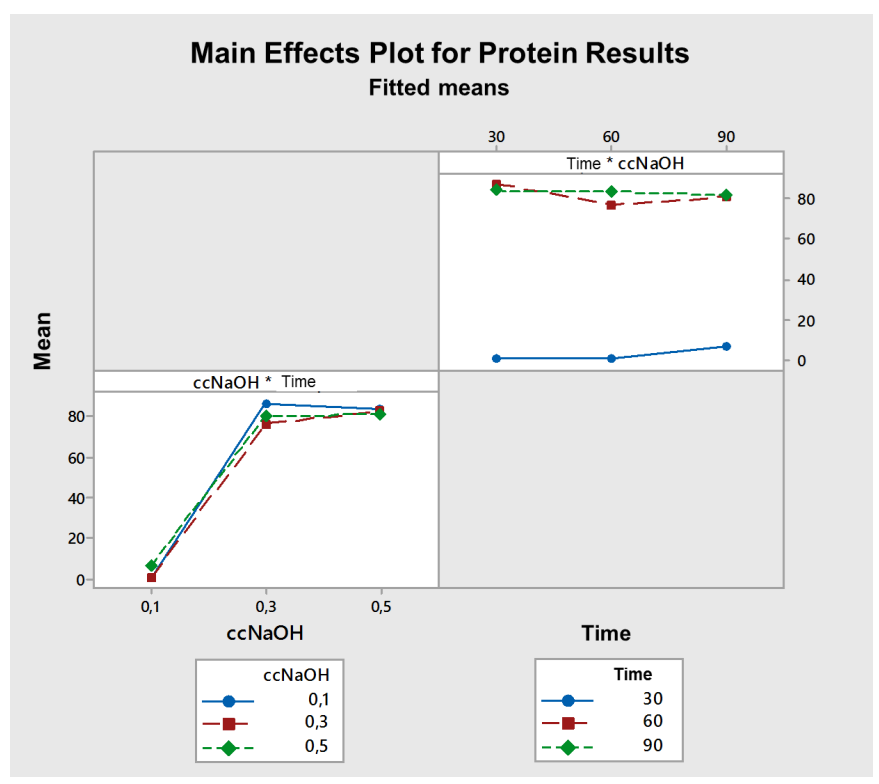

Figure 6. Main Effects Chart for PRCP

Figure 6 presents the behavior of the variable $\mathrm{PRCP}$, where a marked curvature is observed by increasing the concentration of $\mathrm{NaOH}$ and producing an increment of the recovered protein. This variation is explained by the rise of the hydrolytic action over collagen fibers as their basicity increases [21]. According to the plot, the reaction time has no effect in PRCP.

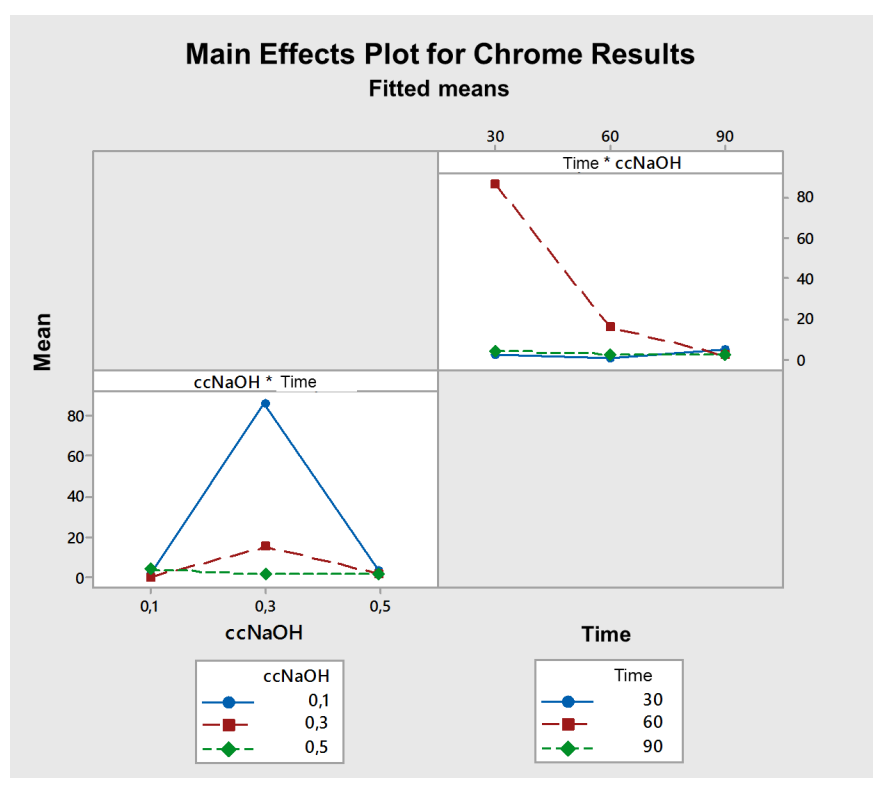

Figure 7. Main Effects Chart for PRC

Figure 7 shows the behavior of the variable PRC in the hydrolysate, observing a curvature in reaction time with the increase in $\mathrm{NaOH}$ concentration. At $0,1 \mathrm{M}$ concentration of $\mathrm{NaOH}$, there is a low percentage of residual chromium, due to the low hydrolytic action. At 0,3 M of $\mathrm{NaOH}$, the percentage of residual chromium is above $85 \%$ at reaction time 30 minutes, but decreases as reaction time goes by, and at 90 minutes, a low percentage of residual chromium is observed, this behaviour is because a greater hydrolysis of the collagen fibers is achieved, in this case, in contrast with the observed with the variable PRCP, the reaction time plays an important role, weakening the bond between collagen fibers and chromium complexes, and 
making it possible to separate them $[14,21]$. Finally, at $0,5 \mathrm{M}$ of $\mathrm{NaOH}$, a low percentage of residual chromium was obtained, because the hydrolytic action at this concentration is higher and faster than in other concentrations of $\mathrm{NaOH}$. It is possible to separate chromium from collagen fibers, resulting in a hydrolysate with a low percentage of residual chromium. Another remarkable point is the chromium cake, it is not only composed of impurities and chromium, it also has a small part of collagen protein, so that means chromium precipitates still attached to some amino acids.

The fit model for the experimental design was calculated from the experimental data. For the PRCP, the determination coefficient $\mathrm{R}^{2}=99.88 \%$ and the adjusted determination coefficient $R_{\text {aj }}^{2}=99.77 \%$ were obtained, showing a clear variability of the $3^{2}$ factorial design model [22]. Thus, the equation of the adjusted model obtained as:

$R_{1}=-59,7905-0,3417 * A+798,93 * B+0,00357 *$

$A^{2}-0,339771 * A * B-964,825 * B^{2}$

$$
\begin{aligned}
& A=\text { Reaction time } \\
& B=N a O H \text { Concentration } \\
& R_{1}=\text { Percentage of recovered collagen }
\end{aligned}
$$

protein

For the PRC, the value of the determination coefficient $R^{2}=98.52 \%$ and the adjusted determination coefficient $R^{2}{ }_{\text {aj }}=97.21 \%$. Hence, $3^{2}$ factorial design model explains well the variability present in the PRC results. The equation of the adjusted model is presented below:

$R_{2}=22,214-1,84347 * A+496,142 * B+0,011917 *$ $A^{2}-0,189167 * A * B-805,811 * B^{2}$

Where:

$$
\begin{aligned}
& A=\text { Reaction time } \\
& B=N a O H \text { Concentration } \\
& R_{2}=\text { Percentage of residual chromium }
\end{aligned}
$$

By using the above equations, the estimated response surfaces for each response variables (collagen and chromium) were obtained, as presented in Figures 8 and 9, respectively.

Where:

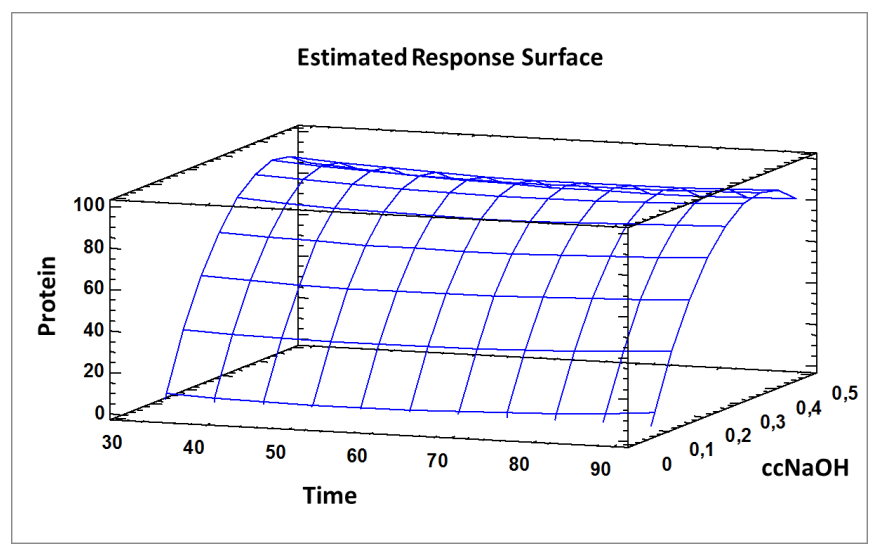

Figure 8. Response surface for PRCP

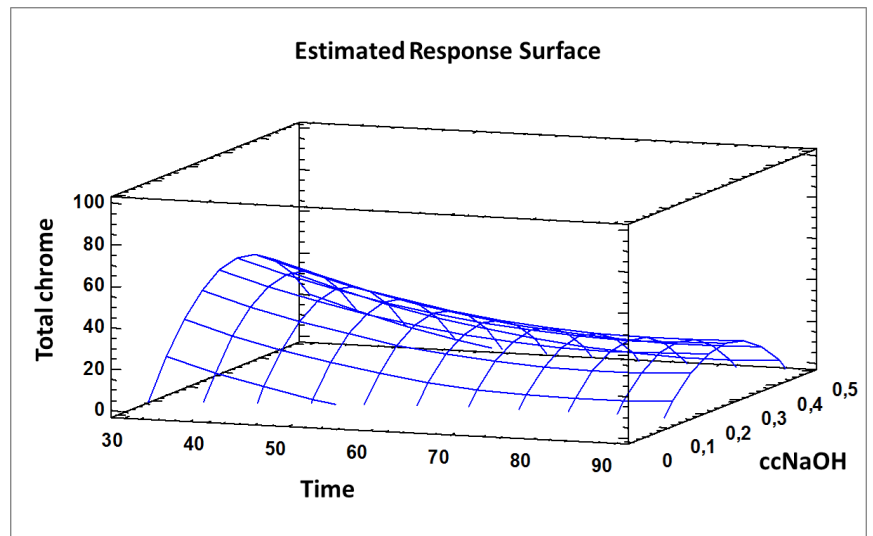

Figure 9. Response surface for PRC 
Analyzing the models for PRCP and PRC, and in order to obtain a hydrolysate with the highest amount of recovered collagen protein and the lowest possible content of chromium, both response variables were optimized simultaneously. For that purpose, a desirability function was established, which tested different points of the design and simultaneously optimized both response variables. Figure 10 presents the estimated response surface for the Desirability function.

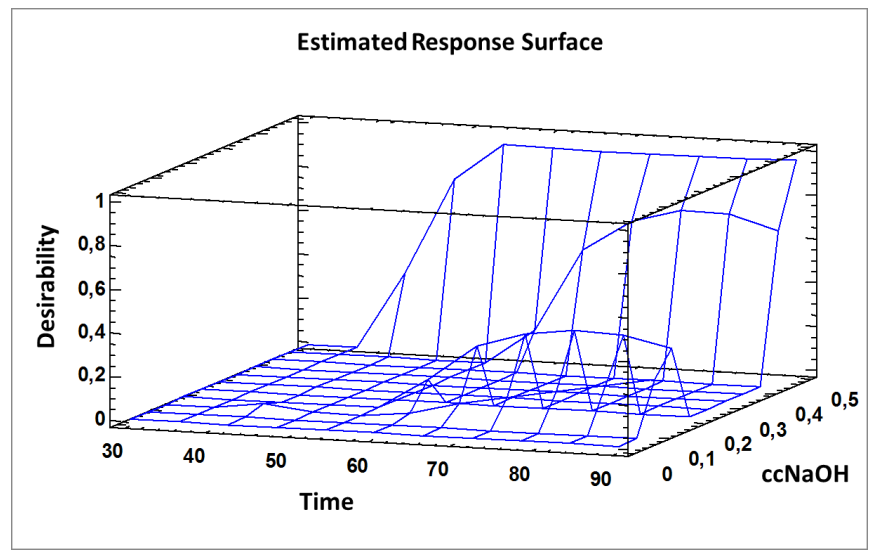

Figure 10. Response surface for the Desirability function

The optimal values for the desirability function were identified as $0.47 \mathrm{M}$ concentration of sodium hydroxide and 90 minutes of reaction time. Under the above conditions, and using the desirability function, it is possible to maximize the percentage of recovered collagen protein as $86.3927 \%$ and minimize the percentage of residual chromium as $0.0329 \%$.

The results obtained in the present study are found to be similar to that by Tahiri et al. [11]. In those cases, the alkaline hydrolysis was optimized to a concentration of $0.5 \mathrm{M}$ of $\mathrm{NaOH}$. Notably, at a higher concentration of $\mathrm{NaOH}$, the hydrolysate would present an excessive amount of salt [11], hence the lower concentration of $\mathrm{NaOH}$ is required to optimize the process. Pahlawan et al. [16] reported the concentration of $3 \% \mathrm{NaOH}$ (equivalent to 0.75 M) with 3 hours of reaction time as the best conditions for the alkaline hydrolysis, resulting in $6.64 \%$ protein in the hydrolysate of collagen, and chromium content of 47.55 ppm. Hussien [21] showed that even chromium has amphoteric nature (precipitates in alkaline solution), it can be dissolved in strong alkali concentration, thus maximizing the percentage of chromium recovery in the cake and minimizing it in the collagen solution.

It is necessary to point out that other studies $[11,13,15]$ considered to evaluate different reaction temperatures, in the present research it was chosen to work at $70^{\circ} \mathrm{C}$ because this temperature was optimal in alkaline hydrolysis research [15, 17-19], and in order to evaluate and compare the relation between reaction time and sodium hydroxide concentration, the temperature was set at that level. Besides, the solubility of chromium increases in the hightemperature range, i.e., $80-100^{\circ} \mathrm{C}$, resulting in an increase in the difficulty of separating the chromium ions from the hydrolysate. In contrast, at a lower temperature range, i.e., $40-60^{\circ}$, the alkaline hydrolysis reaction could be slower, with reaction times that could vary from 2 to 6 hours [11, 13, 15, 17-19].

\section{Scaling up Results}

To scale up the results, the process conditions were adjusted due to the minimum operating capacity of the reactor, as shown in Table 6. 
Table 6: Hydrolysis conditions at pilot scale

\begin{tabular}{cccc}
\hline \multicolumn{2}{c}{$\begin{array}{c}\text { Chromium shavings (kg) } \\
\text { Quantity of Water }(\%, \mathrm{~L})\end{array}$} & $1250 \%$ & $50 \mathrm{~L}$ \\
\hline Sample code & Temperature $(\stackrel{\circ}{ } \mathrm{C})$ & $\begin{array}{c}\mathrm{CC} \mathrm{NaOH} \\
(\mathrm{M})\end{array}$ & $\begin{array}{c}\text { Time } \\
(\mathrm{min})\end{array}$ \\
\hline VC-HP-01 & 70 & 0.45 & 120 \\
\hline
\end{tabular}

In the hydrolysis process on pilot scale, 45 liters of collagen hydrolysate were obtained with PRCP recovered of $87.16 \%$ and PRC of $1.17 \%$.

At the pilot scale, the amount of water was higher, so the concentration of $\mathrm{NaOH}$ had to be lower than the optimized value for $\mathrm{NaOH}$. About the results, the PRCP and PRC in the hydrolysate were higher than those obtained in the optimized model. However, the variation is within the expected range, as explained before, when chromium precipitates into the chromium cake, it is still attached to a small part of collagen, that would explain why the higher PRC also leads to a slight increase in the PRCP, because a small part of chromium has not precipitated. Therefore, the results satisfy the established model, as these are similar to the optimum values. The chromium content of the hydrolysate is higher than that of the model, but it remains low and is not relevant here, as the hydrolysate is meant to be used as retanning agent in the tanning process. The chromium cake, which has the main component of chromium hydroxide can be converted to form basic chromium sulfate, and the remaining waste, composed by secondary nutrients, can be used as fertilizer.

The application of the alkaline hydrolysis makes the process easier to control compared to others, where it is necessary to control $\mathrm{pH}$ and demands higher reactions time. These results show the feasibility to scale up the chrome shavings hydrolysis process, for a higher production of hydrolysate with a high protein amount and low chromium content.

\section{CONCLUSIONS}

In the present research, it was possible to identify the relationship between reaction conditions and response variables, where the increase in $\mathrm{NaOH}$ concentration allows the hydrolysis reaction to occur, and then the increase in the reaction time allows the separation of chromium adhered to the collagen chain. In addition, to establish the optimal conditions and to carry out the alkaline hydrolysis of chrome shavings, the temperature must be $70^{\circ} \mathrm{C}$, the reaction time of 90 minutes and $\mathrm{NaOH}$ concentration of $0.47 \mathrm{M}$. Under these conditions, it is not only possible to recover a high percentage of collagen protein but also to get a hydrolysate with a low percentage of residual chromium. On a pilot scale, it was possible to valorize chrome shavings by recovering hydrolysate with a percentage of recovered collagen protein of $87.16 \%$ and a percentage of residual chromium of $1.17 \%$ and also obtained $750.80 \mathrm{~g}$ of dry chromium cake, reducing the amount of chromium that can be a potential pollutant substance. In addition, the process mainly creates chromium hydroxide, which is the principal component of the chromium cake and can be treated to obtain basic chromium sulfate, which can be reintroduced to the tanning process. Finally, it is recommended evaluate the application of collagen hydrolysate produced in the retanning stage of the tanning process, comparing its effectiveness with a reference commercial re-tanning agent and recover basic chromium salts from the chromium hydroxide recovered from the chromium cake, to evaluate its application in the tanning stage of the tanning process.

\section{Acknowledgements}

We acknowledge to the Productive Innovation and Technological Transfer Center of Leather, Footwear and related industries (CITEccal Lima) and all its staff for the support provided to carry out this project. Likewise, to the Direction of Research, Development, Innovation and Technological Transfer of the Technological Institute of Production (ITP) for the facilities to carry out the laboratory stage in its facilities and to the Faculty of Sciences of the 
National University of Engineering (UNI Perú) for the access to its laboratories, where the scaling up of the project was carried out.

\section{REFERENCES}

1. Santos, C., Bértola, C.E., Valorización de residuos sólidos en la industria del cuero CITEC. Cent Panam Ing Sanit y Ciencias del Ambient, 1999, $n^{\circ}$ 20, CIC-ISNN 03251233.

2. INESCOP, FECUR, Promoción de la cultura medioambiental en el sector del curtido, Valencia, España, 1999, 31-48.

3. China Leather and Footwear Industry, Developing countries training course on ecoleather manufacture technology, Beijing, China, 2007, 592.

4. Pillai, P., Archana, G., A novel process for biodegradation and effective utilization of chrome shavings, a solid waste generated in tanneries, using chromium resistant Bacillus subtilis P13, Process Biochem, 2012, 47, 12, 2116-22, https://doi.org/10.1016/j. procbio.2012.07.030.

5. Qiang, X., Feng, H., Collagen extracted from chrome shavings using alkali and Enzyme, International Conference on Remote Sensing, Environment and Transportation Engineering RSETE 2011 - Proceedings, 2011, 5810-3.

6. Sharaf, S.A.A., Gasmeleed, G.A., Musa, A.E., Extraction of Chromium Six from Chrome Shavings, Journal of Forest Products and Industries, 2013, 2, 2, 21-6.

7. Dias da Silva, L.I., Marinho Pontes, F.V., Castro Carneiro, M., Couto Monteiro, M.I., Dominguez de Almeida, M., Alcover Neto, A., Evaluation of the chromium bioavailability in tanned leather shavings using the SM\&T sequential extractions scheme, Chem Spec Bioavailab, 2015, 23, 3, 183-7, https://doi.or g/10.3184/095422911X13027118597382.

8. Ogata, K., Kumazawa, Y., Koyama, Y., Yoshimura, K., Takahashi, K., Inhibition of generation of hexavalent chromium for chrome-tanned leather with collagen peptide and radical scavenge, XXXIII IULTCS Congress, Novo Hamburgo, Brasil, 2015, 1-8.

9. Mwinyihija, M., Ecotoxicological Diagnosis in the Tanning Industry, New York, NY: Springer New York, 2010, 157, https://doi. org/10.1007/978-1-4419-6266-9_4
10. Nigam, H., Das, M., Chauhan, S., Pandey, P., Swati, P., Yadav, M. et al., Effect of chromium generated by solid waste of tannery and microbial degradation of chromium to reduce its toxicity: A review, Adv Appl Sci Res, 2015, 6, 3, 129-36, available from: http://www. imedpub.com/articles/effect-of-chromiumgenerated-by-solid-waste-of-tannery-andmicrobialdegradation-of-chromium-toreduce-its-toxicity.pdf

11. Tahiri, S., Bouhria, M., Albizane, A., Messaoudi, A., Azzi, M., Younssi, S.A. et al., Extraction of proteins from chrome shavings with sodium hydroxide and reuse of chromium in the tanning process, $J \mathrm{Am}$ Leather Chem Assoc, 2004, 99, 1, 16-25, available from: https://www.researchgate. net/publication/261179769_Extraction_ of_proteins_from_chrome_shavings_ with_sodium_hydroxide_and_reuse_of_ chromium_in_tanning_process

12. Mu, C., Lin, W., Zhang, M., Zhu, Q., Towards zero discharge of chromium-containing leather waste through improved alkali hydrolysis, Waste Manag, 2003, 23, 9, 835-43, https://doi.org/10.1016/S0956053X(03)00040-0.

13. Jiang, T., Zhang, C., Qin, F., Reclamation treatment of the chrome leather scrap, J Environ Sci, 2000, 12, 3, 375-9.

14. Beltrán-Prieto, J.C., Kolomaznik, K., Optimization of alkaline hydrolysis of chrome shavings for chromium oxide recovery, Int $J$ Arts Sci, 2012, 5, 4, 1-13.

15. Scopel, B., De Matos, E.F., Berwig, K.H., Dettmer, A., Baldasso, C., Otimização do processo de extração de proteína de resíduos de couro curtido ao cromo por hidrólise, in: XXI Congresso Brasileiro de Engenharia Química, Fortaleza, Brasil, 2016, p. 8.

16. Pahlawan, I.F., Sutyasmi, S., Griyanitasari, G., Hydrolysis of leather shavings waste for protein binder, IOP Conf Ser Earth Environ Sci, 2019, 230, 1, https://doi.org/10.1088/17551315/230/1/012083.

17.Jordán Núñez, M.F., Obtención decolágenopor hidrólisis alcalina-enzimática del residuo de "wet blue" en el proceso de curtición, Escuela Superior Politécnica de Chimborazo, 2011, available from: http://dspace.espoch.edu.ec/ bitstream/123456789/1468/1/34T00246.pdf 
18. Niculescu, M., Bajenaru, S., Gaidau, C., Simion, D., Filipescu, L., Extraction of the protein components as amino-acids hydrolysates from chrome leather wastes through hydrolytic processes, Rev Chim, 2009, 60, 10, 1070-8.

19. Kupec, J., Dvorackova, M., Rudlova, S., Ru, J., Kolomazník, K., Deproteination of Chrome waste by washing and enzymatic hydrolysis, J Am Leather Chem Assoc, 2002, 97, 349-54.

20. NMX-F-274-1984, DETERMINACIÓN DEL GRADO BRIX EN MUESTRAS DE MELADURA; MASAS COCIDAS; MIELES " $A$ " $Y$ " $B$ " DE REFINERIA $Y$ MIEL FINAL. POR MÉTODO HIDROMÉTRICO, México; 1984, p. 13, available from: https://www. colpos. $\mathrm{mx} /$ bancodenormas/nmexicanas/ NMX-F-274-1984.PDF.
21. Hussien, M., Preparation of Collagen Hydrolysate Syntan From Delimed Pelt Trimmings for Post Tanning Application and for Stabilizing Collagen Fibers, Addis Ababa University - Ethiopia, 2014, 102 p.

22. Gutiérrez, H., De la Vara, R., Análisis y Diseño de Experimentos, 3rd Ed., New York, NY: McGraw-Hill, 2012, 506 p.

(C) 2020 by the author(s). Published by INCDTPICPI, Bucharest, RO. This is an open access article distributed under the terms and conditions of the Creative Commons Attribution license (http://creativecommons.org/licenses/by/4.0/). 